\title{
Decreased Serum Retinoic Acid May Predict Poor Outcome in Ischemic Stroke Patients
}

This article was published in the following Dove Press journal:

Neuropsychiatric Disease and Treatment

\section{Mengshi $X u^{1, *}$ \\ Liang $X \mathrm{u}^{2, *}$ \\ Huaping $\mathrm{Du}^{\prime}$ \\ Wanying Shan' \\ Jie Feng' \\ Guojie Zhai \\ Xiuyan Yang'}

'Department of Neurology, Suzhou Ninth People's Hospital, Suzhou, Jiangsu 215200, People's Republic of China; ${ }^{2}$ Department of Anesthesiology, The First Affiliated Hospital of Soochow University, Suzhou, Jiangsu 215000,

People's Republic of China

*These authors contributed equally to this work
Correspondence: Xiuyan Yang; Guojie

Zhai

Email yangxiuyan335@163.com;

12546|985@qq.com
Background and Aims: Decreased serum retinoic acid (RA) levels have been shown to be linked with increased mortality in cardiovascular diseases. This study aimed to investigate the relationship between serum RA and 3-month functional outcome after ischemic stroke.

Methods: Between January 2019 and September 2019, we prospectively recruited ischemic stroke patients within 24 hrs of symptom onset. Serum RA levels were measured for all patients at admission. The primary outcome was defined as poor functional outcome (modified Rankin Scale 3-6) at 90 days. The secondary outcome was defined as early neurological deterioration (END), which is considered as an increase of $\geq 1$ point in motor power or total National Institutes of Health Stroke Scale score of $\geq 2$ points within 7 days.

Results: A total of 217 patients were included in the analysis. The median RA levels were $2.9 \mathrm{ng} / \mathrm{mL}$. Ninety-four (43.3\%) and $65(30.0 \%)$ patients experienced 3-month poor outcome and END, respectively. After adjusted for potential confounders, decreased levels of serum RA were associated with a higher risk of poor outcome $(P$ for trend $=0.001)$ and END $(P$ for trend $=0.002)$. Adding RA quartile to the existing risk factors improved risk prediction for poor outcome [net reclassification improvement $(\mathrm{NRI})=42.6 \%, P=0.001$; integrated discrimination improvement $(\mathrm{IDI})=5.7 \%, P=0.001]$ and $\mathrm{END}(\mathrm{NRI}$ index $=45.4 \%, P=$ $0.001 ;$ IDI $=4.3 \% ; P=0.005)$.

Conclusion: Low serum RA levels at baseline were associated with poor prognosis at 90 days after ischemic stroke, suggesting that RA may be a potential prognostic biomarker for ischemic stroke.

Keywords: acute ischemic stroke, retinoic acid, early neurological deterioration, functional outcome

\section{Introduction}

Epidemiological studies have demonstrated that ischemic stroke is the most common cause of death in China. ${ }^{1}$ Established traditional risk factors, such as advanced age, hypertension and diabetes mellitus, can only explain part of poor prognosis of patients. $^{2-4}$ Because of the high risk of disability and mortality after ischemic stroke, it is urgent to determine novel biomarkers to improve the prediction of stroke outcomes.

As a major active metabolite of vitamin A, retinoic acid (RA) functions as a natural ligand for receptors, such as retinoic acid receptor, retinoid $\mathrm{X}$ receptor, and nuclear hormone receptors, and regulates the transcription of various kinds of genes controlling cell differentiation, embryonic development and physiologic homeostasis. $^{5-7}$ A number of experimental studies suggested that RA is critical in the adult brain. ${ }^{8,9}$ Data from animal studies showed that RA supplementation could 
protect neurons against ischemic damage and help to decrease infarction volume after focal brain ischemia. ${ }^{10-12}$ RA was also found to be able to ameliorate blood-brain barrier disruption following ischemic stroke in rats. ${ }^{13}$ In clinical study, low serum RA was proved to be independently associated with post-stroke cognitive impairment and affective disorder. ${ }^{14,15}$ In another prospective study focusing on acute ischemic stroke patients, decreased circulating levels of RA were reported to be correlated with increased risk of all-cause mortality or cardiovascular disease mortality in the 6 months after symptoms onset. ${ }^{16}$ All these studies indicated that RA might be a prognostic biomarker for ischemic stroke. However, the clinical relevance of circulating RA in the short-term stroke outcomes has not been clarified. The aim of this study was to investigate whether serum RA levels were associated with 3-month functional outcome and early neurological deterioration (END) in patients with ischemic stroke.

\section{Methods}

\section{Study Design and Patients}

From Jan 2019 to Sep 2019, patients, who were admitted to Suzhou Ninth People's Hospital, with first-ever acute ischemic stroke were screened for inclusion in our study. Patients were recruited if they met the following criteria: 1) aged 18 years or old; 2) time lapse between the symptom onset and hospitalization $<24 \mathrm{hrs}$; 3) had pre-onset modified Rankin Scale (mRS) score $\leq 2$. Patients with intravenous thrombolysis and endovascular therapy, tumor, severe renal disease and hepatic disease and discharge within 7 days were all excluded from this study. The local institutional review boards of Suzhou Ninth People's Hospital approved that all study procedures were performed in accordance with relevant guidelines and regulations (NO. SZJY-20181207). All patients or their relatives provided written informed consent and agreed to participate in the study.

\section{Data Collection}

After admission, demographic characteristic, clinical data and medical history were collected in all patients. Stroke severity was assessed using National Institutes of Health Stroke Scale ${ }^{17}$ by trained neurologists. Stroke etiology was classified according to the Trial of the ORG 10172 in Acute Stroke Treatment (TOAST) criteria, ${ }^{18}$ which embraces large artery atherosclerosis, cardioembolism, small vessel occlusion, stroke of other determined etiology and cryptogenic stroke. Laboratory data including levels of lipid profile, blood glucose, hypersensitive C-reactive protein (Hs-CRP) and homocysteine were also recorded.

\section{Serum RA Measurement}

After informed consents' blood samples were collected from all patients on the second day morning. The specimens were centrifuged at $1500 \mathrm{~g}$ for $10 \mathrm{~min}$ and the isolated plasma frozen at $-80^{\circ} \mathrm{C}$ for further analysis. Serum RA concentrations were measured using a commercially available ELISA kit (Cat. MBS705877, MyBioSource, San Diego, CA). The detection range of $\mathrm{RA}$ is $0.625-10 \mathrm{ng} / \mathrm{mL}$. The intra-assay and interassay coefficient of variation were $<8.0 \%$. The measurement of serum RA was performed by laboratory technicians who were blind to any clinical information of the study participants.

\section{Assessment of Outcomes}

The primary outcome was assessed as functional outcome at 3 months by trained neurologists who were blinded to clinical data using modified Rankin Scale (mRS). According to previous studies, poor functional outcome was defined as modified Rankin Scale score of 3-6. ${ }^{19,20}$ The secondary end point in stroke patients was END. In our study, END was defined as an increase of $\geq 1$ point in motor power or $\geq 2$ points in total NIHSS score within 7 days after admission. ${ }^{21,22}$

\section{Statistical Analysis}

Categorical variables were expressed as $n(\%)$ and continuous variables as means (standard deviation) or medians (interquartile range). Differences in baseline characteristics between groups were analyzed using chi-square test or Fisher's exact test, analysis of variance, or Kruskal-Wallis test where appropriate. Logistic regression analysis was used to estimate the risk of stroke outcomes by calculating odds ratios (OR) and 95\% confidence interval (CI). Variables with $P$ value $<0.1$ in univariate analysis were adjusted in multiple regression analysis. In addition, net reclassification index (NRI) and integrated discrimination improvement (IDI) were calculated to evaluate the predictive value of adding RA to conventional risk factors model. Receiver operating characteristic (ROC) curves were used to describe RA levels as a potential predictive factor for stroke outcomes. The area under curve (AUC) was calculated based on the ROC curves. Two-tailed $P<$ 0.05 was considered to be statistically significant. All 
analyses were performed using SPSS software, version 22.0 (IBM, New York, NY) and R statistical software version 3.6.2.

\section{Results}

A total of 217 participants (mean age $66.5 \pm 9.4$ years, $52.5 \%$ male) were included in this prospective study. The median RA concentration was $2.9 \mathrm{ng} / \mathrm{mL}$ (interquartile range, 2.0-5.2 $\mathrm{ng} / \mathrm{mL}$ ) with quartile levels as follows: $<2.0 \mathrm{ng} / \mathrm{mL}$ (1st quartile), $2.0-2.9 \mathrm{ng} / \mathrm{mL}$ (2nd quartile), 3.0-5.2 ng/mL (3rd quartile), and $>5.2 \mathrm{ng} / \mathrm{mL}$ (4th quartile).

After follow-up of 3 months, a total of 94 patients (43.3\%) experienced poor outcome (Table 1). Compared with participants who did not develop poor outcome, those who developed were more likely to have higher systolic blood pressure, NIHSS score, Hs-CRP, and prevalence of diabetes mellitus and lower RA levels (Table 1). Sixty-five (30.0\%) patients were diagnosed as END during hospitalization. Table 2 shows the baseline data between the subgroup according to the presence or absence of END. Compared with patients without END, those with it were older, more likely to have higher levels of Hs-CRP, fasting blood-glucose, homocysteine, and lower levels of RA and more prevalence of diabetes mellitus.

Table 3 summarizes the results of the binary logistic regression of the clinical outcomes. The 1st quartile of RA levels (using the 4th quartile as the reference value) was identified as the predictor of poor outcome [odds ratio (OR), 4.485; 95\% CI 1.890-9.639; $P$ for trend $=0.001]$ after adjusted for systolic blood pressure, NIHSS score, Hs-CRP and diabetes mellitus. Moreover, decreased serum RA was associated with a higher risk of END ( $P$ for trend $=0.002$ ) after adjusted for age, Hs-CRP, fasting bloodglucose, Hs-CRP, homocysteine and diabetes mellitus. This association remained statistically significant when RA levels were analyzed as continuous variables.

We further examined whether adding serum RA to the conventional risk factors improved the risk prediction of clinical outcomes after acute ischemic stroke. As shown in Table 4, adding RA quartile to conventional risk factors significantly improved predictive power for poor outcome $[\mathrm{NRI}=42.6 \%, P=0.001 ; \mathrm{IDI}=5.7 \%, P=0.001]$ and END (NRI $=45.4 \%, P=0.001$; IDI $=4.3 \% ; P=0.005)$. Similarly, significant findings were observed when RA levels were analyzed as continuous variables. To detect the possible predictive value of RA for stroke outcomes, area under curve (AUC) was used to compare the prediction accuracy between the model with and without RA.
The AUC of poor outcome (from 0.661 to 0.713 ) and END (from 0.744 to 0.776 ) were increased when RA was put into the model (Figure 1).

\section{Discussion}

In the present study, we assessed the correlation between serum RA levels and short-term prognosis of ischemic stroke. We found that decreased RA levels at baseline were independently associated with higher risk of poor outcome developed at 3 months and END after ischemic stroke, even after adjustment for several potential confounders. Furthermore, adding RA to conventional risk factors could improve risk prediction for the stroke outcomes. These findings indicated that serum RA might be a potential biomarker in the prediction of clinical outcomes among acute ischemic stroke patients. Further studies from various populations are needed to replicate our findings.

$\mathrm{RA}$ is a major metabolic product from vitamin A, which can only be obtained from diet including carotenoids and retinyl esters. ${ }^{23}$ Cumulative epidemiological evidences indicate that specific circulating vitamins had numerous health benefits as well as protective effects on the progression of coronary artery disease. ${ }^{24,25}$ As the substrate for the active all-trans RA, retinol was confirmed to be able to predict coronary events in healthy middleaged men in the PRIME study. ${ }^{26}$ Several population-based studies have investigated the association between serum RA levels and clinical outcomes in cardiovascular disease. ${ }^{16,27}$ After measurement of serum RA levels in 1499 patients with angiographically confirmed coronary artery disease in the Guangdong Coronary Artery Disease Cohort, Liu et $\mathrm{al}^{27}$ found that high RA levels (defined as $>$ median) were associated with a lower risk of total mortality (adjusted hazard ratios, 0.68; 95\% CI, $0.50-0.85 ; \quad P=0.001)$ and cardiovascular mortality (adjusted hazard ratios, 0.62; 95\% CI, 0.45-0.78; $P<$ $0.001)$. Furthermore, in a cohort of patients with firstever acute ischemic stroke, RA levels in 2nd quartile, 3rd quartile, and 4th quartile were correlated with allcause mortality, and the mortality was decreased by $31 \%$ (OR 0.69; 95\% CI, 0.55-0.89), 52\% (OR 0.48; 95\% CI, $0.34-0.60$ ), and 82\% (OR 0.18; 95\% CI, 0.11-0.29) respectively. ${ }^{16}$ Our study extended the current knowledge about the role of serum RA in acute ischemic stroke as it shows a strongly prognostic value in the presence of 3-month poor outcome and END. Previous studies also confirmed a negative association between RA level and 
Table I Characteristics of Ischemic Stroke Patients with and Without Poor Outcome at 3-Month

\begin{tabular}{|c|c|c|c|}
\hline Variables & Poor Outcome $(n=94)$ & Good Outcome $(n=123)$ & $P$ value \\
\hline $\begin{array}{l}\text { Demographic characteristics } \\
\text { Age, year } \\
\text { Male, n (\%) }\end{array}$ & $\begin{array}{l}66.9 \pm 9.3 \\
49(52.1)\end{array}$ & $\begin{array}{l}66.0 \pm 9.6 \\
65(52.8)\end{array}$ & $\begin{array}{l}0.571 \\
0.916\end{array}$ \\
\hline $\begin{array}{l}\text { Risk factors, } \mathrm{n}(\%) \\
\text { Hypertension } \\
\text { Diabetes mellitus } \\
\text { Hyperlipidemia } \\
\text { Coronary heart disease } \\
\text { Current smoking }\end{array}$ & $\begin{array}{l}65(69.1) \\
35(37.2) \\
15(16.0) \\
7(7.4) \\
31(33.0)\end{array}$ & $\begin{array}{l}90(73.2) \\
32(26.0) \\
24(19.5) \\
17(13.8) \\
38(30.9)\end{array}$ & $\begin{array}{l}0.516 \\
0.076 \\
0.499 \\
0.138 \\
0.744\end{array}$ \\
\hline $\begin{array}{l}\text { Clinical data } \\
\text { Systolic blood pressure, } \mathrm{mmHg} \\
\text { Diastolic blood pressure, } \mathrm{mmHg} \\
\text { Body mass index, } \mathrm{kg} / \mathrm{m}^{2} \\
\text { NIHSS, score }\end{array}$ & $\begin{array}{l}139.4 \pm 16.7 \\
84.4 \pm 12.4 \\
24.5 \pm 1.9 \\
7.0(3.0,9.0)\end{array}$ & $\begin{array}{l}133.5 \pm 18.4 \\
85.8 \pm 10.8 \\
24.7 \pm 1.6 \\
6.0(3.0,8.0)\end{array}$ & $\begin{array}{l}0.017 \\
0.3847 \\
0.461 \\
0.045\end{array}$ \\
\hline $\begin{array}{l}\text { Stroke etiology, } \mathrm{n}(\%) \\
\text { Large vessel disease } \\
\text { Cardioembolic } \\
\text { Small vessel disease } \\
\text { Stroke with determined etiology } \\
\text { Cryptogenic stroke }\end{array}$ & $\begin{array}{l}49(52.1) \\
11(11.7) \\
26(27.7) \\
4(4.3) \\
4(4.3)\end{array}$ & $\begin{array}{l}53(43.1) \\
9(7.3) \\
40(32.5) \\
6(4.9) \\
15(12.2)\end{array}$ & 0.161 \\
\hline $\begin{array}{l}\text { Stroke location, } \mathrm{n}(\%) \\
\text { Lobar } \\
\text { Basal ganglia } \\
\text { Infratentorial } \\
\text { Others }\end{array}$ & $\begin{array}{l}27(28.7) \\
26(27.7) \\
10(10.6) \\
31(33.6)\end{array}$ & $\begin{array}{l}22(17.9) \\
37(30.1) \\
20(16.3) \\
44(35.8)\end{array}$ & 0.239 \\
\hline $\begin{array}{l}\text { Laboratory data } \\
\text { Total cholesterol, } \mathrm{mmol} / \mathrm{L} \\
\text { Triglyceride, mmol/L } \\
\text { Low density lipoprotein, } \mathrm{mmol} / \mathrm{L} \\
\text { High density lipoprotein, } \mathrm{mmol} / \mathrm{L} \\
\text { Hs-CRP, } \mathrm{mg} / \mathrm{L} \\
\text { Fasting blood-glucose, } \mathrm{mmol} / \mathrm{L} \\
\text { Homocysteine, } \mathrm{mmol} / \mathrm{L}\end{array}$ & $\begin{array}{l}4.6 \pm 1.1 \\
1.6 \pm 0.9 \\
2.4 \pm 0.9 \\
1.4 \pm 0.3 \\
4.1(1.0,9.5) \\
6.5 \pm 2.3 \\
15.4 \pm 8.2\end{array}$ & $\begin{array}{l}4.6 \pm 1.2 \\
1.5 \pm 0.8 \\
2.3 \pm 0.8 \\
1.4 \pm 0.4 \\
3.2(1.0,6.2) \\
6.6 \pm 2.2 \\
15.6 \pm 6.8\end{array}$ & $\begin{array}{l}0.472 \\
0.588 \\
0.698 \\
0.951 \\
0.008 \\
0.791 \\
0.784\end{array}$ \\
\hline $\mathrm{RA}$ levels, $\mathrm{ng} / \mathrm{mL}$ & $2.5(1.6,4.5)$ & $3.6(2.3,5.8)$ & 0.002 \\
\hline $\begin{array}{l}\text { RA quartile } \\
\text { Ist } \\
\text { 2nd } \\
3 \text { rd } \\
4 \text { th }\end{array}$ & $\begin{array}{l}31(33.0) \\
27(28.7) \\
20(21.3) \\
16(17.0)\end{array}$ & $\begin{array}{l}23(18.7) \\
28(22.8) \\
33(26.8) \\
39(31.7)\end{array}$ & 0.015 \\
\hline
\end{tabular}

Abbreviations: Hs-CRP, hyper-sensitive C-reactive protein; NIHSS, National Institutes of Health Stroke Scale; RA, retinoic acid.

diabetes mellitus. ${ }^{15}$ In our study, the level of RA was slightly lower in patients with diabetes mellitus than those without it (median level, $2.7 \mathrm{ng} / \mathrm{mL}$ vs $3.2 \mathrm{ng} / \mathrm{mL}$ ). However, the difference did not reach statistical significance $(P=0.258)$, probably due to the difference in study population, and sample size. Further studies with large sample size might be useful to clarify this association.

The mechanisms underlying the detrimental effects of decreased RA on the stroke prognosis are still poorly clear, but several potential pathophysiological pathways may be 
Table 2 Characteristics of Ischemic Stroke Patients with and Without END

\begin{tabular}{|c|c|c|c|}
\hline Variables & With END $(n=65)$ & Without END $(n=152)$ & $P$ value \\
\hline $\begin{array}{l}\text { Demographic characteristics } \\
\text { Age, year } \\
\text { Male, n (\%) }\end{array}$ & $\begin{array}{l}68.7 \pm 9.1 \\
34(52.3)\end{array}$ & $\begin{array}{l}65.6 \pm 9.4 \\
80(52.6)\end{array}$ & $\begin{array}{l}0.026 \\
0.965\end{array}$ \\
\hline $\begin{array}{l}\text { Risk factors, } \mathrm{n}(\%) \\
\text { Hypertension } \\
\text { Diabetes mellitus } \\
\text { Hyperlipidemia } \\
\text { Coronary heart disease } \\
\text { Current smoking }\end{array}$ & $\begin{array}{l}48(73.8) \\
31(47.7) \\
14(21.5) \\
8(12.3) \\
19(29.2)\end{array}$ & $\begin{array}{l}107(70.4) \\
36(23.7) \\
25(16.4) \\
16(10.5) \\
50(32.9)\end{array}$ & $\begin{array}{l}0.606 \\
0.001 \\
0.371 \\
0.702 \\
0.595\end{array}$ \\
\hline $\begin{array}{l}\text { Clinical data } \\
\text { Systolic blood pressure, } \mathrm{mmHg} \\
\text { Diastolic blood pressure, } \mathrm{mmHg} \\
\text { Body mass index, } \mathrm{kg} / \mathrm{m}^{2} \\
\text { NIHSS, score }\end{array}$ & $\begin{array}{l}\mid 38.3 \pm 18.1 \\
84.9 \pm 11.5 \\
24.7 \pm 1.7 \\
6.0(3.5,8.0)\end{array}$ & $\begin{array}{l}135.1 \pm 17.8 \\
85.3 \pm 11.6 \\
24.8 \pm 1.8 \\
6.5(2.0,9.0)\end{array}$ & $\begin{array}{l}0.220 \\
0.837 \\
0.754 \\
0.176\end{array}$ \\
\hline $\begin{array}{l}\text { Stroke etiology, } \mathrm{n}(\%) \\
\text { Large vessel disease } \\
\text { Cardioembolic } \\
\text { Small vessel disease } \\
\text { Stroke with determined etiology } \\
\text { Cryptogenic stroke }\end{array}$ & $\begin{array}{l}34(52.3) \\
6(9.2) \\
20(30.8) \\
4(6.2) \\
I(1.5)\end{array}$ & $\begin{array}{l}68(44.7) \\
14(9.2) \\
46(30.3) \\
6(3.9) \\
18(11.8)\end{array}$ & 0.161 \\
\hline $\begin{array}{l}\text { Stroke location, } \mathrm{n}(\%) \\
\text { Lobar } \\
\text { Basal ganglia } \\
\text { Infratentorial } \\
\text { Others }\end{array}$ & $\begin{array}{l}19(29.2) \\
22(33.8) \\
6(9.2) \\
18(27.7)\end{array}$ & $\begin{array}{l}30(19.7) \\
41(27.0) \\
24(15.8) \\
57(37.5)\end{array}$ & 0.155 \\
\hline $\begin{array}{l}\text { Laboratory data } \\
\text { Total cholesterol, } \mathrm{mmol} / \mathrm{L} \\
\text { Triglyceride, } \mathrm{mmol} / \mathrm{L} \\
\text { Low density lipoprotein, } \mathrm{mmol} / \mathrm{L} \\
\text { High density lipoprotein, } \mathrm{mmol} / \mathrm{L} \\
\text { Hs-CRP, } \mathrm{mg} / \mathrm{L} \\
\text { Fasting blood-glucose, } \mathrm{mmol} / \mathrm{L} \\
\text { Homocysteine, } \mathrm{mmol} / \mathrm{L}\end{array}$ & $\begin{array}{l}4.7 \pm 1.2 \\
1.5 \pm 0.6 \\
2.4 \pm 0.8 \\
1.4 \pm 0.3 \\
5.0(2.2,9.2) \\
7.0 \pm 2.2 \\
17.1 \pm 9.4\end{array}$ & $\begin{array}{l}4.6 \pm 1.1 \\
1.6 \pm 0.9 \\
2.3 \pm 0.9 \\
1.3 \pm 0.3 \\
3.0(1.0,6.0) \\
6.3 \pm 2.3 \\
14.9 \pm 6.4\end{array}$ & $\begin{array}{l}0.551 \\
0.511 \\
0.703 \\
0.621 \\
0.001 \\
0.027 \\
0.045\end{array}$ \\
\hline RA levels, ng/mL & $2.6(1.7,3.9)$ & $3.4(2.1,5.6)$ & 0.018 \\
\hline $\begin{array}{l}\text { RA quartile } \\
\text { Ist } \\
\text { 2nd } \\
\text { 3rd } \\
\text { 4th }\end{array}$ & $\begin{array}{l}23(35.4) \\
20(30.8) \\
12(18.5) \\
10(15.4)\end{array}$ & $\begin{array}{l}31(20.4) \\
35(23.0) \\
41(27.0) \\
45(29.6)\end{array}$ & 0.017 \\
\hline
\end{tabular}

Abbreviations: END, early neurological deterioration; Hs-CRP, hyper-sensitive C-reactive protein; NIHSS, National Institutes of Health Stroke Scale; RA, retinoic acid.

involved. Acute ischemic stroke can trigger a widespread inflammatory response to induce neuronal damages, characterized by increasing pro-inflammatory cytokines and disrupting blood-brain barrier. ${ }^{28}$ Experimental study indicated that RA can suppress inflammatory reactions through mediating the expression of pro-inflammatory mediators (including IL-1 $\beta$, IL-6, TNF- $\alpha$ and SAA) and increasing CD14 and MHC II percent positive cells. ${ }^{29}$ RA supplementation was also found to substantially ameliorate blood-brain barrier disruption following ischemic stroke in 
Table 3 Logistics Regression Analysis for the Association Between RA Levels and Clinical Outcomes Among Ischemic Stroke Patients

\begin{tabular}{|c|c|c|c|c|}
\hline & OR $(95 \% \mathrm{Cl})$ for 3-Month Unfavorable Outcome & $P$ value & OR $(95 \% \mathrm{Cl})$ for END & $P$ value \\
\hline \multicolumn{5}{|c|}{ Unadjusted model } \\
\hline RA levels & $0.823(0.718-0.942)$ & 0.005 & $0.821(0.706-0.954)$ & 0.011 \\
\hline $\begin{array}{l}\text { RA quartile } \\
\text { Ist } \\
\text { 2nd } \\
\text { 3rd } \\
\text { 4th }\end{array}$ & $\begin{array}{l}3.285(I .486-7.264) \\
2.350(I .07 I-5.159) \\
I .477(0.66 I-3.302) \\
\text { Reference }\end{array}$ & & $\begin{array}{l}3.339(1.396-7.985) \\
2.57 \mid(1.068-6.189) \\
1.317(0.515-3.37 I) \\
\text { Reference }\end{array}$ & \\
\hline$P$ for trend & 0.018 & & 0.021 & \\
\hline \multicolumn{5}{|c|}{ Adjusted model } \\
\hline RA levels & $0.763(0.655-0.888)$ & 0.001 & $0.785(0.665-0.927)$ & 0.004 \\
\hline $\begin{array}{l}\text { RA quartile } \\
\text { Ist } \\
\text { 2nd } \\
\text { 3rd } \\
\text { 4th }\end{array}$ & $\begin{array}{l}4.485(1.890-9.639) \\
3.111(1.318-7.334) \\
1.572(0.657-3.762) \\
\text { Reference }\end{array}$ & & $\begin{array}{l}3.995(1.5 \mid 7-9.821) \\
3.552(1.319-9.562) \\
1.622(0.575-4.574) \\
\text { Reference }\end{array}$ & \\
\hline$P$ for trend & 0.001 & & 0.002 & \\
\hline
\end{tabular}

Abbreviations: $\mathrm{Cl}$, confidence interval; $\mathrm{END}$, early neurological deterioration; OR, odds ratio; RA, retinoic acid.

rats. ${ }^{13}$ Besides, increased oxidative stress plays an essential role in brain tissue injury after stroke. ${ }^{30}$ Previous evidence suggested that RA administration at a physiological concentration significantly decreased hyperglycemia-induced oxidative stress and thus supported the antioxidant defense system. ${ }^{31}$ Taken together, we speculated that the anti-inflammatory and antioxidative stress characteristics of RA may exert protection on the stroke brain. The endogenous expression of RA can be induced after brain tissue injury, which could create a dynamic signaling environment for neurons and glia, and therefore improve functional recovery. ${ }^{32}$ Interestingly, preclinical animal models have also confirmed the neuroprotective therapeutic role of the application of RA receptor agonist in intracerebral hemorrhage. ${ }^{33}$ Taken together, whether the management of serum RA levels within an appropriate range could improve stroke outcomes is a possible future area of inquiry.

Our study has several limitations that need to be noted. First, this study was a single-center observational study. Therefore, there may exist a selection bias and limit the generalizability of the findings to other ethnicities. Second, patients with intravenous thrombolysis, endovascular therapy, tumor, severe renal disease and

Table 4 Reclassification and Discrimination Statistics for Clinical Outcomes by RA Levels Among Ischemic Stroke Patients

\begin{tabular}{|c|c|c|c|c|c|}
\hline \multirow[t]{2}{*}{ Clinical Outcomes } & \multirow[t]{2}{*}{ Model } & \multicolumn{2}{|l|}{ Continuous NRI } & \multicolumn{2}{|l|}{ IDI } \\
\hline & & Estimate $(95 \% \mathrm{Cl})$ & $P$ value & Estimate $(95 \% \mathrm{Cl})$ & $P$ value \\
\hline 3-month poor outcome & $\begin{array}{l}\text { Conventional model }^{\mathrm{a}} \\
\text { Conventional model + RA (continuous) } \\
\text { Conventional model + RA (quartiles) }\end{array}$ & $\begin{array}{l}0.397(0.138-0.657) \\
0.426(0.164-0.688)\end{array}$ & $\begin{array}{l}0.003 \\
0.001\end{array}$ & $\begin{array}{l}0.052(0.023-0.082) \\
0.057(0.026-0.089)\end{array}$ & $\begin{array}{l}0.001 \\
0.001\end{array}$ \\
\hline END & $\begin{array}{l}\text { Conventional model }^{\mathrm{b}} \\
\text { Conventional model + RA (continuous) } \\
\text { Conventional model + RA (quartiles) }\end{array}$ & $\begin{array}{l}0.442(0.169-0.714) \\
0.454(0.176-0.734)\end{array}$ & $\begin{array}{l}0.005 \\
0.001\end{array}$ & $\begin{array}{l}0.036(0.011-0.063) \\
0.043(0.013-0.072)\end{array}$ & $\begin{array}{l}0.008 \\
0.005\end{array}$ \\
\hline
\end{tabular}

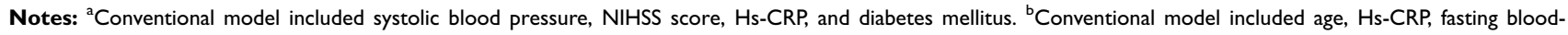
glucose, homocysteine, and diabetes mellitus.

Abbreviations: $\mathrm{Cl}$, confidence interval; END, early neurological deterioration; IDI, integrated discrimination index; NRI, net reclassification improvement; RA, retinoic acid. 

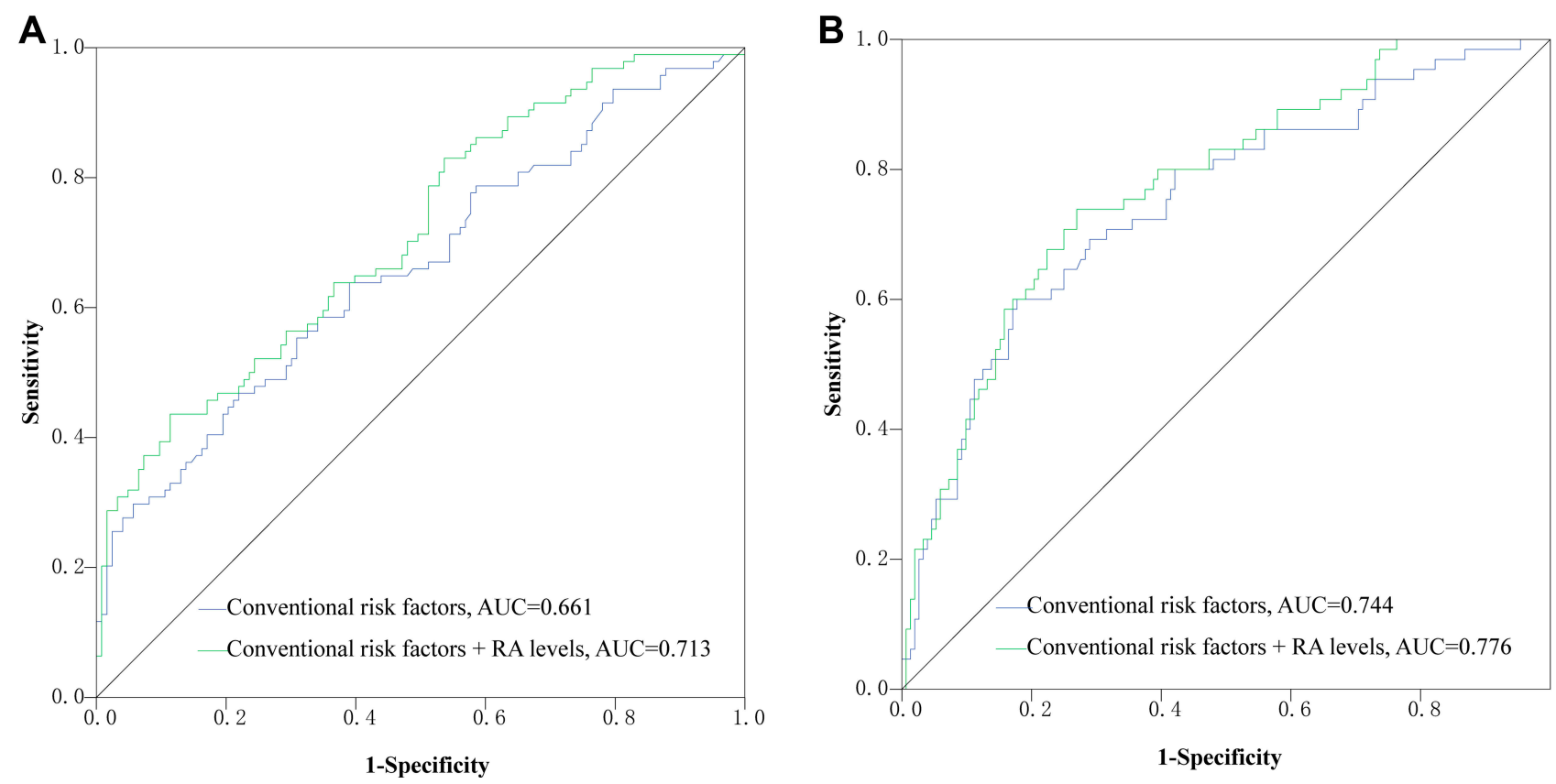

Figure I ROC curves comparing the potential of different models to predict stroke outcomes (A,B).

hepatic disease and early discharge were excluded, which might induce an underestimation of the actual incidence of END and poor outcome. Third, circulating RA concentrations were measured only once at admission, so we were unable to investigate the association between changes in serum RA and prognosis of ischemic stroke. Finally, RA concentrations and activity may be affected by many other factors, including retinol dehydrogenase 10, alcohol dehydrogenase, retinaldehyde dehydrogenase, and cytochrome $\mathrm{P} 450$ and thyroid hormone receptor. Thus, the effects of these confounding factors cannot be excluded in our study.

\section{Conclusions}

In conclusion, our data demonstrated that low serum RA levels at acute phase were associated with short-term prognosis among ischemic stroke patients, indicating that RA may be a potential prognostic biomarker for ischemic stroke. We suggest that further prospective studies from other populations of ischemic stroke are needed to validate our findings. Potential pathophysiological mechanisms and therapeutic considerations also remain to be determined.

\section{Data Sharing Statement}

The data that support the findings of this study are available on request from the corresponding author.

\section{Ethics Approval and Informed Consent}

All procedures performed in studies involving human participants were in accordance with the ethical standards of Suzhou Ninth People's Hospital and with the 1964 Helsinki declaration and its later amendments or comparable ethical standards. All patients or their relatives provided written informed consent and agreed to participate in the study.

\section{Author Contributions}

All authors contributed to data analysis, drafting and revising the article, gave final approval of the version to be published, and agree to be accountable for all aspects of the work.

\section{Disclosure}

All authors declare that they have no conflicts of interest.

\section{References}

1. Zhou M, Wang H, Zhu J, et al. Cause-specific mortality for 240 causes in China during 1990-2013: a systematic subnational analysis for the global burden of disease study 2013. Lancet. 2016;387(10015): 251-272.

2. Mohan K, Crichton S, Grieve A, Rudd A, Wolfe C, Heuschmann P. Frequency and predictors for the risk of stroke recurrence up to 10 years after stroke: the south london stroke register. J Neurol Neurosurg Psychiatry. 2009;80(9):1012-1018. doi:10.1136/jnnp.2008.170456 
3. Hillen T, Coshall C, Tilling K, Rudd A, McGovern R, Wolfe C. Cause of stroke recurrence is multifactorial: patterns, risk factors, and outcomes of stroke recurrence in the south london stroke register. Stroke. 2003;34(6):1457-1463. doi:10.1161/01.STR.0000072985. 24967.7F

4. Wolfe C, Crichton S, Heuschmann P, et al. Estimates of outcomes up to ten years after stroke: analysis from the prospective south london stroke register. PLoS Med. 2011;8(5):e1001033. doi:10.1371/journal. pmed.1001033

5. Rice B, Cifelli C, Pikosky M, Miller G. Dairy components and risk factors for cardiometabolic syndrome: recent evidence and opportunities for future research. Adv Nutr. 2011;2(5):396-407. doi:10.3945/ an. 111.000646

6. Niederreither K, Dollé P. Retinoic acid in development: towards an integrated view. Nat Rev Genet. 2008;9(7):541-553. doi:10.1038/ nrg2340

7. Germain P, Chambon P, Eichele G, et al. International union of pharmacology. Lx. Retinoic acid receptors. Pharmacol Rev. 2006;58 (4):712-725. doi:10.1124/pr.58.4.4

8. McCaffery P, Zhang J, Crandall J. Retinoic acid signaling and function in the adult hippocampus. J Neurobiol. 2006;66(7):780-791. doi:10.1002/neu.20237

9. Mishra S, Kelly K, Rumian N, Siegenthaler J. Retinoic acid is required for neural stem and progenitor cell proliferation in the adult hippocampus. Stem Cell Rep. 2018;10(6):1705-1720. doi:10.10 16/j.stemcr.2018.04.024

10. Li L, Li Y, Ji X, Zhang B, Wei H, Luo Y. The effects of retinoic acid on the expression of neurogranin after experimental cerebral ischemia. Brain Res. 2008;1226:234-240. doi:10.1016/j.brainres. 2008.06.037

11. Shen H, Luo Y, Kuo C, et al. 9-cis-retinoic acid reduces ischemic brain injury in rodents via bone morphogenetic protein. $J$ Neurosci Res. 2009;87(2):545-555. doi:10.1002/jnr.21865

12. Yu S, Airavaara M, Wu K, et al. 9-cis retinoic acid induces neuro repair in stroke brain. Sci Rep. 2017;7(1):4512. doi:10.1038/s41598017-04048-2

13. Kong L, Wang Y, Wang X, et al. Retinoic acid ameliorates blood-brain barrier disruption following ischemic stroke in rats. Pharmacol Res. 2015;99:125-136. doi:10.1016/j.phrs.2015.05.014

14. Hou L, Ding C, Chen Z, et al. Serum retinoic acid level and the risk of poststroke cognitive impairment in ischemic stroke patients. J Stroke Cerebrovasc Dis. 2019;28(11):104352. doi:10.1016/j. jstrokecerebrovasdis.2019.104352

15. Duan Z, Shan W, Du H, et al. Association between serum retinoic acid levels and risk of post-stroke depression in patients with ischemic stroke. Asian J Psychiatr. 2019;46:87-91. doi:10.1016/j. ajp.2019.09.038

16. Tu W, Qiu H, Zhang Y, et al. Lower serum retinoic acid level for prediction of higher risk of mortality in ischemic stroke. Neurology. 2019;92(15):e1678-e1687. doi:10.1212/WNL.0000000000007261

17. Goldstein L, Samsa G. Reliability of the national institutes of health stroke scale. Extension to non-neurologists in the context of a clinical trial. Stroke. 1997;28(2):307-310. doi:10.1161/01.STR.28.2.307

18. Adams HJ, Bendixen B, Kappelle L, Biller J, Love B, Gordon D. Classification of subtype of acute ischemic stroke. Definitions for use in a multicenter clinical trial. Toast. Trial of org 10172 in acute stroke treatment. Stroke. 1993;24(1):35-41. doi:10.1161/01.STR.24.1.35
19. Guo D, Zhu Z, Zhong C, et al. Increased serum netrin-1 is associated with improved prognosis of ischemic stroke. Stroke. 2019;50 (4):845-852. doi:10.1161/STROKEAHA.118.024631

20. Zhu Z, Guo D, Zhong C, et al. Serum dkk-1 (dickkopf-1) is a potential biomarker in the prediction of clinical outcomes among patients with acute ischemic stroke. Arterioscler Thromb Vasc Biol. 2019;39(2):285-293. doi:10.1161/ATVBAHA.118.311960

21. Zhang X, Sun Z, Ding C, et al. Metabolic syndrome augments the risk of early neurological deterioration in acute ischemic stroke patients independent of inflammatory mediators: a hospital-based prospective study. Oxid Med Cell Longev. 2016;2016:8346301. doi:10.1155/2016/8346301

22. Kwon H, Lee Y, Bae H, Kang D. Homocysteine as a predictor of early neurological deterioration in acute ischemic stroke. Stroke. 2014;45(3):871-873. doi:10.1161/STROKEAHA.113.004099

23. von Lintig J. Provitamin a metabolism and functions in mammalian biology. Am J Clin Nutr. 2012;96(5):1234S-1244S. doi:10.3945/ ajen.112.034629

24. Friso S, Girelli D, Martinelli N, et al. Low plasma vitamin b-6 concentrations and modulation of coronary artery disease risk. $\mathrm{Am}$ J Clin Nutr. 2004;79(6):992-998. doi:10.1093/ajcn/79.6.992

25. Gholami F, Moradi G, Zareei B, et al. The association between circulating 25-hydroxyvitamin $\mathrm{d}$ and cardiovascular diseases: a meta-analysis of prospective cohort studies. BMC Cardiovasc Disord. 2019;19(1):248. doi:10.1186/s12872-019-1236-7

26. Gey K, Ducimetière $P$, Evans $A$, et al. Low plasma retinol predicts coronary events in healthy middle-aged men: the prime study. Atherosclerosis. 2010;208(1):270-274. doi:10.1016/j.atherosclerosis.20 09.07.018

27. Liu Y, Chen H, Mu D, et al. Association of serum retinoic acid with risk of mortality in patients with coronary artery disease. Circ Res. 2016;119(4):557-563. doi:10.1161/CIRCRESAHA.116.308781

28. Jin R, Liu L, Zhang S, Nanda A, Li G. Role of inflammation and its mediators in acute ischemic stroke. J Cardiovasc Transl Res. 2013;6 (5):834-851. doi:10.1007/s12265-013-9508-6

29. Abdelhamid L, Hussein H, Ghanem M, Eissa N. Retinoic acid-mediated anti-inflammatory responses in equine immune cells stimulated by lps and allogeneic mesenchymal stem cells. Res Vet Sci. 2017;114:225-232. doi:10.1016/j.rvsc.2017.05.006

30. Rodrigo R, Fernández-Gajardo R, Gutiérrez R, et al. Oxidative stress and pathophysiology of ischemic stroke: novel therapeutic opportunities. CNS Neurol Disord Drug Targets. 2013;12(5): 698-714. doi:10.2174/1871527311312050015

31. Guleria R, Pan J, Dipette D, Singh U. Hyperglycemia inhibits retinoic acid-induced activation of rac1, prevents differentiation of cortical neurons, and causes oxidative stress in a rat model of diabetic pregnancy. Diabetes. 2006;55(12):3326-3334. doi:10.2337/db060169

32. Kelly K, MacPherson A, Grewal H, et al. Colla1+ perivascular cells in the brain are a source of retinoic acid following stroke. $B M C$ Neurosci. 2016;17(1):49. doi:10.1186/s12868-016-0284-5

33. Matsushita H, Hijioka M, Hisatsune A, et al. A retinoic acid receptor agonist am80 rescues neurons, attenuates inflammatory reactions, and improves behavioral recovery after intracerebral hemorrhage in mice. J Cereb Blood Flow Metab. 2011;31(1):222-234. doi:10.1038/ jcbfm.2010.80 


\section{Publish your work in this journal}

Neuropsychiatric Disease and Treatment is an international, peerreviewed journal of clinical therapeutics and pharmacology focusing on concise rapid reporting of clinical or pre-clinical studies on a range of neuropsychiatric and neurological disorders. This journal is indexed on PubMed Central, the 'PsycINFO' database and CAS, and is the official journal of The International Neuropsychiatric Association (INA). The manuscript management system is completely online and includes a very quick and fair peer-review system, which is all easy to use. Visit http://www.dovepress.com/testimonials.php to read real quotes from published authors. 